\title{
Phosphorus dynamics of the procaryotic nannoplankton in a Michigan lake ${ }^{1}$
}

\author{
John T. Lehman \\ Division of Biological Sciences and Great Lakes Research Division, \\ University of Michigan, Ann Arbor 48109
}

Craig D. Sandgren

Department of Biology, University of Texas, Arlington 76019

\begin{abstract}
The small-celled cyanobacteria that dominate Third Sister Lake, Michigan, during summer have extraordinary uptake capabilities for phosphate. Under enriched conditions, the cells can double their phosphorus content in 2 min or less but can sustain the high rates for only a few minutes. With equal initial access to the nutrient, the small procaryotes are ultimately more successful than are coexisting eucaryotes in converting the nutrient into new cell biomass.
\end{abstract}

Quantifying the movement of phosphorus among dissolved, colloidal, and particulate phases in a lake is often prerequisite to deciphering plankton dynamics, because production is often guided by the quantity and rate of supply of that essential nutrient. Ambient concentrations of soluble reactive $\mathrm{P}$ (SRP) are often below the limits of chemical detection in surface waters, and limnologists have known for decades that even the traces measured chemically may overestimate by an order of magnitude or more the actual pool, presumably $\mathrm{PO}_{4}{ }^{3-}$, that is most actively sequestered by the phytoplankton (Kuenzler and Ketchum 1962; Rigler 1966, 1968; Brown et al. 1978; Levine and Schindler 1980). Despite concentrations of $\mathrm{PO}_{4}{ }^{3-}$ assumed to be in the nanomolar range or lower the cells are able to fuel their growth and division at rates which could be supported by ambient pools for only a fraction of the day.

When flux rates for $\mathrm{P}$ are measured by the addition of tracer radiophosphorus, investigators can demonstrate that pools turn over in a matter of minutes (Lean 1973; Rigler 1973; Berman and Skyring 1979). The dynamics are characterized by wholesale exchange of $\mathrm{P}$ among its di-

\footnotetext{
1 This study was supported by National Science Foundation grant DEB79-22143.
}

verse phases in the water. The exchange rates are calculated from measurements of only one side of a two-way flux whose difference may be close to zero (Lehman 1980). That difference is net uptake, and it represents the $\mathrm{P}$ that has been accumulated and is available for growth. The outcome of competition among the plankton for the nutrient depends on relative abilities for net uptake and not merely on exchange rates per se.

When investigators have argued that either bacterioplankton or phytoplankton are responsible for the major measured flux of $\mathrm{P}$ at ambient concentrations (Burnison 1975; Pearl and Lean 1976), some disagreement has resulted from a failure to divorce the subject of exchange fluxes from genuine net uptake. We found it necessary to address this issue when we discovered an abrupt and dramatic change within a period of 2 wecks in the response of phytoplankton in Third Sister Lake, Michigan, to added P. We will illustrate that an approach which focuses on measured net uptake in response to nutrient perturbations provides a useful way to resolve the problems.

\section{Methods}

Experiments were conducted with water collected from $1 \mathrm{~m}$ below the surface of Third Sister Lake, a 16-m-deep kettle lake in southern Michigan. The 
water was transported to the laboratory in a 20-liter Nalgene carboy and used for experiments at ambient temperature $\left(25^{\circ} \pm\right.$ $2^{\circ} \mathrm{C}$ ) within $4 \mathrm{~h}$.

Pigments were measured spectrophometrically using GF/F glass-fiber filters, 90\% acetone, and Lorenzen's correction for pheopigments (Strickland and Parsons 1972). Soluble reactive $P$ was measured by the molybdate-ascorbic acid method (Strickland and Parsons 1972). Total $\mathrm{P}$ was measured after persulfate oxidation (Menzel and Corwin 1965) followed by neutralization and analysis for SRP as above.

Lake water samples were fractioned according to particle size by sieving them through Nitex polyamide nylon (Tetko, Inc.) of requisite aperture size. Aperture dimensions were confirmed microscopically. When several liters of lake water had to be centrifuged for experiments, we used a Sorval centrifuge fitted for continuous flow operation. Flow rate and rpm were adjusted in each case so that virtually all particles filterable on a GF/F filter were removed from the water.

For P uptake experiments, water samples were dispensed to 1- or 2-liter Erlenmeyer flasks and the $\mathrm{PO}_{4}{ }^{3-}$ concentration was delivered as $\mathrm{KH}_{2} \mathrm{PO}_{4}$ from a Finnpipette. Immediately after addition the flask was swirled and about $100 \mathrm{ml}$ was poured through a rinsed $0.45-\mu \mathrm{m}$ Millipore filter. Replicate $40-\mathrm{ml}$ water samples for SRP analysis were drawn from this filtrate and the reagent was added within $1 \mathrm{~min}$. The sampling procedure was repeated at intervals and samples were measured as soon as color stabilized. This made it possible to compute concentrations and to make repeated $\mathrm{PO}_{4}{ }^{3-}$ additions to specified levels in some experiments. When total dissolved $\mathrm{P}$ (DP) was to be measured as well, additional water was filtered and set aside for analysis.

Phytoplankton were identified and counted using an Olympus IMT inverted microscope. Five-milliliter samples of plankton preserved in Lugol's solution were settled overnight and at least 15 random fields counted at $600 \times$ magnifi- cation with bright-field optics. Cell volumes were estimated from clay models crafted to conform to mean estimates of the lengths of major axes.

Bacteria were counted by the method of Hobbie et al. (1977) using an Olympus BHA compound microscope, 100-W mercury burner, 1 or 2 BG-12 and 1 BG-38 exciter filters, blue dichroic mirrors, and a 530-nm barrier filter. The same techniques and system were used to evaluate autofluorescence, except that acridine orange was omitted. Counts were made with either a $60 \times$ fluorite objective and $15 \times$ eyepieces or a $100 \times$ plan apochromatic objective and $10 \times$ eyepieces.

In situ experiments were done in enclosures of clear plastic $0.1 \mathrm{~mm}$ thick and $3 \mathrm{~m}$ long (the thickness of the epilimnion during summer) holding 600 liters. The enclosures were filled using a gasolinepowered centrifugal pump with a thermoplastic impeller; they were secured at the surface by flotation collars and left open to the air. The enclosures were filled with water from 0 to $3 \mathrm{~m}$ by raising the inlet hose while the enclosure was filling. Nutrient treatments consisted of adding $\mathrm{NaNO}_{3}+\mathrm{NaH}_{2} \mathrm{PO}_{4}$ or $\mathrm{NH}_{4} \mathrm{Cl}+\mathrm{Na}$ $\mathrm{H}_{2} \mathrm{PO}_{4}$ to replicate enclosures while the enclosures were filling with water. Replicate controls consisted of lake water only. The pump was used to mix the enclosures thoroughly before samples were removed for biological and chemical analyses.

Some enclosures contained a natural assemblage of zooplankton drawn from the lake with the water. Animals were excluded from other enclosures by sieving the water through a plankton net $(55-\mu \mathrm{m}$ aperture) as the enclosures were filled.

\section{Results}

When enclosures were enriched with 5 $\mu \mathrm{M} \mathrm{PO}_{4}{ }^{3-}$ on 9 June the plankton took up the nutrient in a progressive way, but 2 weeks later when $2 \mu \mathrm{M} \mathrm{PO}_{4}{ }^{3-}$ was added to separate enclosures $90 \%$ of the initial concentration of SRP was removed by the plankton within $1 \mathrm{~h}$ (Fig. 1, upper panel). These findings were confirmed by measurements of total dissolved $P$, illustrat- 
ing that $\mathrm{PO}_{4}{ }^{3-}$ was indeed removed from solution rather than formed into complexes or colloids in the filtrate. Initial rates of $\mathbf{P}$ uptake per liter of lake water differed by more than 100-fold between these experiments and were incompletely explained by differences in total phytoplankton biomass or Chl a (Fig. 1, lower panel). Control enclosures in each experiment showed no significant changes in SRP or Chl $a$ during the same time. Epilimnetic water temperature differed by only $4^{\circ} \mathrm{C}$ between experiments; it was $19^{\circ} \mathrm{C}$ on 11 June and $23^{\circ} \mathrm{C}$ on 24 June. Not only were initial rates of $\mathrm{PO}_{4}{ }^{3-}$ uptake faster in the 24 June experiment, but the concentrations of $\mathrm{Chl} a$ increased much faster in response to the nutrient enrichment, another index of the elevated metabolic activity of the community.

At the start of the 9 June experiment the plankton was dominated by a mixture of eucaryotic species while the nannoplankton cyanobacteria constituted a minor fraction by volume (19.2\%). In this experiment the eucaryotes and cyanobacteria responded similarly to phosphorus and ammonium stimulation, so that the added nutrients were partitioned among all the dominant species (Table 1). The doubling time for cell volume was 2.23 days for the procaryotic and 2.52 for the eucaryotic components. The community structure thus remained relatively stable, with the cyanobacteria constituting $26.2 \%$ of the total cell volume in the final samples.

The results of similar nutrient stimulation were quite different in the 24 June experiment (Table 1). The plankton assemblage initially enclosed on 24 June differed from the 9 June plankton in that the cyanobacteria constituted a much larger fraction of the total cell volume (35.9\%), Fragilaria crotonensis replaced Nitzschia palea as the dominant diatom, cryptomonads essentially had disappeared, and the very small-celled Lyngbya limnetica replaced Oscillatoria sp. as the dominant cyanobacterium. The change in relative density and species composition of the cyanobacteria in the second experiment was correlated with
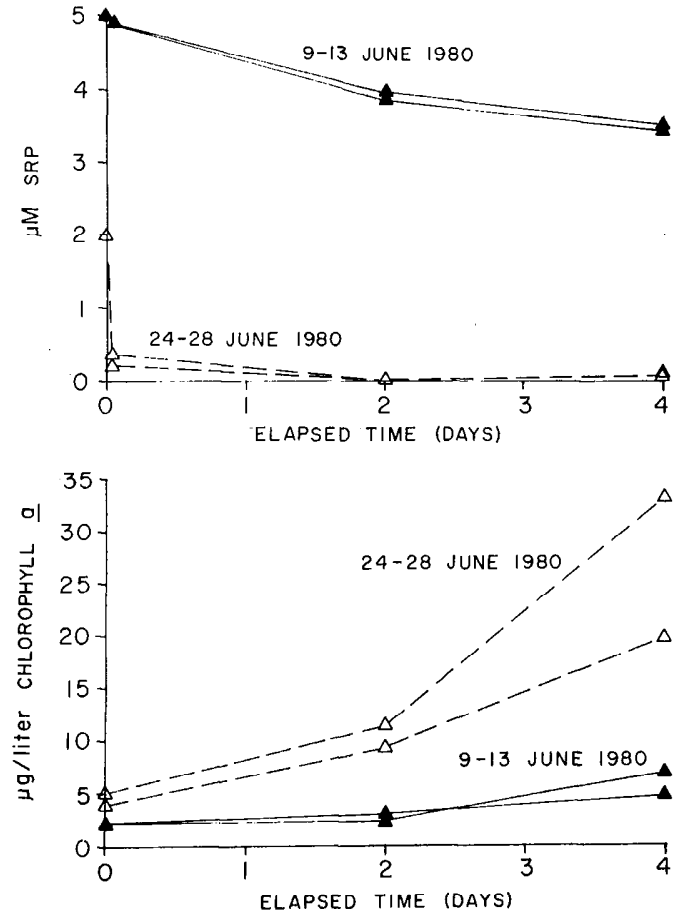

Fig. 1. Measured concentrations of SRP and Chl $a$ during two enclosure experiments in Third Sister Lake. Results are shown for replicate columns. Initial concentrations of SRP were calculated values, confirmed by total P analysis. Enclosures were sampled within $1 \mathrm{~h}$ after nutrients were added.

their almost complete domination of uptake and utilization of the nutrient pulse. The procaryotic nannoplankton constituted $88.2 \%$ of the final cell volume in this experiment and the volumetric doubling times for the cyanobacteria and eucaryotes were 1.12 and 3.76 days. Most of the eucaryotes did not respond significantly to the nutrient enrichment. The only eucaryotic species in the plankton that appeared competitive with the cyanobacteria in terms of turning the nutrient pulse into new cells was $F$. crotonensis which had a volumetric doubling time of 1.00 days.

Parallel with these changes in the structure of the algal community, the unanticipated changes in rates of net uptake of $\mathrm{PO}_{4}{ }^{3-}$ prompted us to ask what components of the assemblage were respon- 
Table 1. Mean percentage of total cell volume contributed by major procaryotic and eucaryotic species in replicate enclosures. Enclosures received additions of both $\mathrm{PO}_{4}{ }^{3-}$ and $\mathrm{NH}_{4}{ }^{+}$.

\begin{tabular}{|c|c|c|c|c|}
\hline & \multicolumn{2}{|c|}{9 Jun $\exp$} & \multicolumn{2}{|c|}{24 Jun exp } \\
\hline & $\begin{array}{l}\text { Initial } \\
\text { (9 Jun) }\end{array}$ & $\begin{array}{c}\text { Final } \\
\text { (20 Jun) }\end{array}$ & $\begin{array}{c}\text { Initial } \\
\text { (24 Jun) }\end{array}$ & $\begin{array}{c}\text { Final } \\
\text { (30 Jun) }\end{array}$ \\
\hline \multicolumn{5}{|l|}{ Procaryotes } \\
\hline Unident. coccoid & 12.1 & 0.4 & 6.5 & 0.3 \\
\hline Microcystis minutissima W. West & 2.7 & 1.9 & 7.9 & 6.9 \\
\hline Oscillatoria sp. & 4.4 & 23.9 & - & - \\
\hline Lyngbya limnetica Lemmermann & - & - & 21.5 & 81.0 \\
\hline Total & 19.2 & 26.2 & 35.9 & 88.2 \\
\hline \multicolumn{5}{|l|}{ Eucaryotes } \\
\hline Nitzschia palea (Kutz.) W. Sm. & 0.8 & 3.0 & - & - \\
\hline Sphaerocystis schroeteri Chodat & 0.0 & 4.7 & - & - \\
\hline Fragilaria crotonensis Kitton & - & - & 1.4 & 5.4 \\
\hline Dictyosphaerium pulchellum Wood & - & - & 1.2 & 0.5 \\
\hline Oocystis pusilla Hansgirg & 2.2 & 24.3 & 24.9 & 2.6 \\
\hline Ankistrodesmus falcatus (Corda) Ralfs. & 1.6 & 2.2 & 2.6 & 0.4 \\
\hline Kirchneriella contorta (Schmidle) Bohlin & 2.3 & 4.7 & 4.9 & 0.4 \\
\hline Chroomonas minuta (Skuja) Bourrelly & 16.2 & 0.4 & 10.8 & 0.04 \\
\hline Ch. nordstedii Hansgirg/Cryptomonas marsonii Skuja & 53.9 & 27.5 & - & - \\
\hline Others & - & - & 18.3 & 2.4 \\
\hline Total & 77.0 & 66.8 & 64.1 & 11.7 \\
\hline Total vol $\left(10^{6} \mu \mathrm{m}^{3} \cdot \mathrm{ml}^{-1}\right)$ & 0.165 & 3.71 & 3.77 & 62.5 \\
\hline
\end{tabular}

sible for the rapid removal of $P$ from solution and whether these components were biotic or abiotic. The second question reflected our concern that adsorption onto small inorganic or organically derived particles might be the mechanism, because the rapid rates were confined to $\mathrm{PO}_{4}{ }^{3-}$ and did not extend to added $\mathrm{NO}_{3}{ }^{-}$ or $\mathrm{NH}_{4}^{+}$.

Most of the uptake activity in fact resided in particles that passed a $5-\mu \mathrm{m}$ sieve but were retained on $\mathrm{GF} / \mathrm{F}$ or $0.45-\mu \mathrm{m}$ Millipore filters (Fig. 2). When lake water was enriched in the lab with $2 \mu \mathrm{M}$ $\mathrm{KH}_{2} \mathrm{PO}_{4}$ and sieved by gravity through Nitex screens, some activity could be ascribed securely to particles $>20 \mu \mathrm{m}$ but about $85 \%$ of the net flux of $\mathrm{P}$ was into the smallest fraction (Fig. 2, lower panel).

The uptake was biotic. Samples concentrated from the lake water by centrifugation were killed with $1 \%$ glutaraldehyde. The samples were then centrifuged in a clinical centrifuge, the supernatant was discarded and the sediment suspended in either filtered lake water or distilled water. The centrifugation and washing were repeated and the particles finally suspended in flasks of 1-liter total volume each. $\mathrm{PO}_{4}{ }^{3-}$ was added to each vessel and the removal of SRP and DP from solution measured at intervals. The killed samples were compared with the original, untreated water and with water subjected to the centrifugation steps but not to the glutaraldehyde. Rates of adsorption onto the nonliving particles were much lower than the rates of uptake by the live treatments (Table 2). Centrifuged samples were not identical to the control in particle concentration owing to dilution at resuspension. Expressed per unit of pigment (Chl $a+$ pheopigments), uptake rates for control and centrifuged treatments are similar and more than an order of magnitude greater than rates in the killed samples. Rates are expressed in terms of total pigments to avoid potential bias from degradation of chlorophyll by the fixative, and more important, by the distilled water rinses in one treatment.

Having recognized that the uptake of $\mathrm{PO}_{4}{ }^{3-}$ was mediated by biotic processes, 

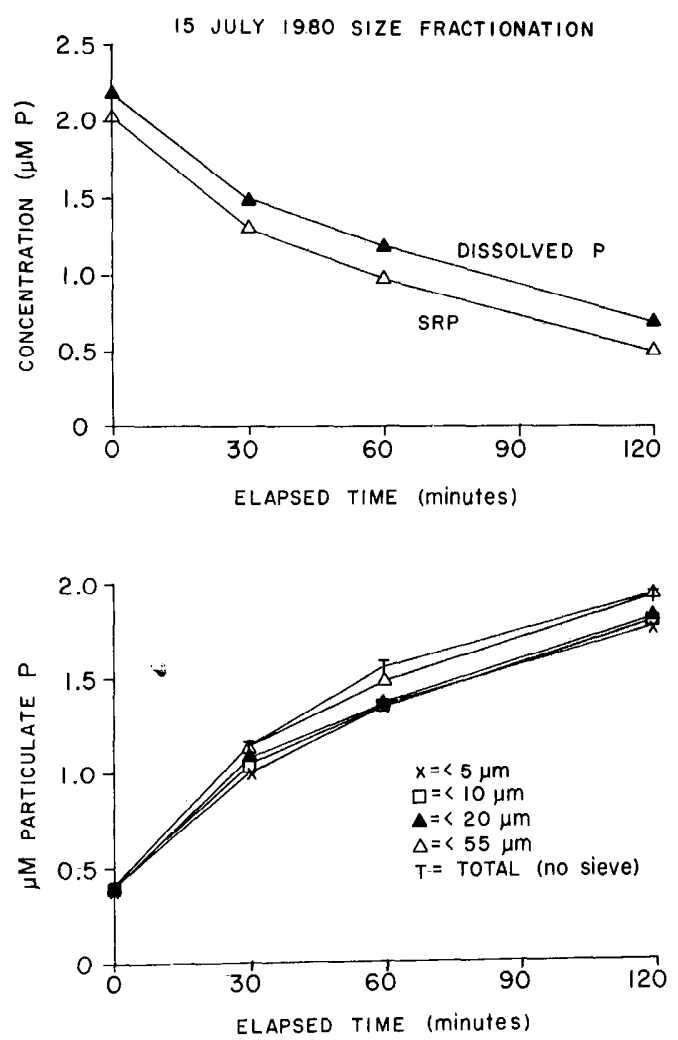

Fig. 2. Changes in SRP, DP, and particulate $P$ in several size fractions following addition of $\mathrm{PO}_{4}{ }^{3-}$ to lake water.

we next measured the process kinctics by charting rates of removal of added $P$ from solution. Rates were computed from the measured change in concentration over intervals of 5 or $10 \mathrm{~min}$ (Fig. 3, upper panels) and assigned to the mean concentration during the intervals (Fig. 3, lower panels). The plankton responded swiftly to the added nutrients by lowering their capacity for maximal uptake rates. In the lower panels of Fig. 3 uptake rates measured over successive intervals after a single $\mathrm{PO}_{4}{ }^{3-}$ addition are connected by solid lines. Within 5 min of first exposure to elevated concentrations of $\mathrm{PO}_{4}^{3-}$, the cells display uptake rates substantially depressed below the rectangular hyperbola that is fit to initial uptake rates. Uptake rates progressively diverge from the predicted initial values with continued exposure to $\mathrm{PO}_{4}{ }^{3-}$.
Table 2. Rates of biotic and abiotic uptake of $P$ in Third Sister Lake. Samples killed with glutaraldehyde were washed with filtered lake water (LW) or with distilled water (DW).

\begin{tabular}{|c|c|c|c|c|}
\hline & \multicolumn{2}{|c|}{ Pigment $\left(\mu \mathrm{g} \cdot\right.$ liter $\left.^{-1}\right)$} & \multicolumn{2}{|c|}{$\begin{array}{l}\text { Uptake (nmol P. } \mu \mathrm{g} \\
\left.\text { pigment }{ }^{-1} \cdot \min ^{-1}\right)\end{array}$} \\
\hline & $\operatorname{Chl} a$ & Pheo $a$ & SRP & DP \\
\hline Control & 7.37 & 1.25 & 5.07 & 5.10 \\
\hline Centrifuged & 3.02 & 0.55 & 4.58 & 4.58 \\
\hline Killed-LW & 2.83 & 0.52 & 0.40 & 0.30 \\
\hline Killed-DW & 2.38 & 1.37 & 0.18 & 0.27 \\
\hline
\end{tabular}

These characteristics can be traced to the small-sized particles $(<5 \mu \mathrm{m})$. More than $80 \%$ of the uptake shown by particles $<55 \mu \mathrm{m}$ could be attributed to those $<5$ $\mu \mathrm{m}$ (Table 3 ). To some extent this was because at least half of the biomass measured as total cell volume or as Chl $a$ resided in the small fraction, but the activities of the small cells were also higher. Even when uptake rates are expressed in terms of chlorophyll biomass the small cells show much faster rates than cells $>5$ $\mu \mathrm{m}$, by a factor of 10 (Fig. 4, Table 3 ).

The $<5-\mu \mathrm{m}$ size fraction from several July plankton samples was heavily dominated by two cyanobacteria: a very narrow-celled species of Lyngbya, L. limnetica Lemmermann, and diffuse colonies of Microcystis of. minutissima W. West. The cell volumes of both were in the range of $0.1-2 \mu \mathrm{m}^{3}$. Small colonies of the diminutive chlorophyte Dictyosphaerium pulchellum Wood were the only eucaryotic cells present in significant densities, but eucaryotes were clearly subdominant ( $10.2 \%$ of total cell volume) to the cyanobacteria. All three species are $\gg 5 \mu \mathrm{m}$ in some dimension of their typical colonial or filamentous habit but apparently were able to pass through the $5-\mu \mathrm{m}$ sieve by fragmentation or fortuitous alignment.

The $<55-\mu \mathrm{m}$ fractions for the same dates contained the same dominant species with the addition of the rigid colonies of a species of Coelosphaerium and many of the eucaryotes reported for the 24 June experiment (Table 1). This fraction contained twice the abundance of 

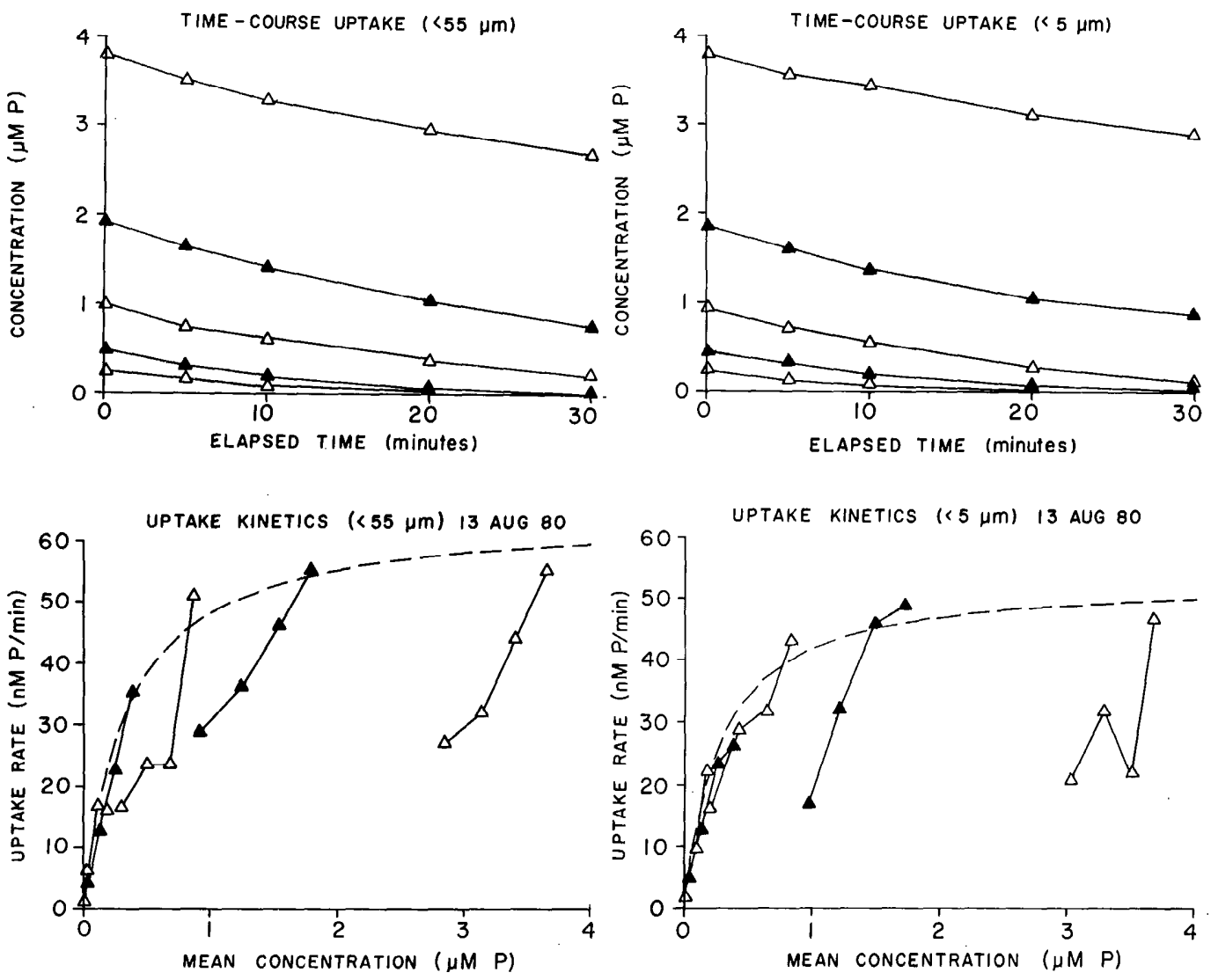

Fig. 3. Uptake kinetics by lake water passed through 55- or 5- $\mu \mathrm{m}$ sieve before $\mathrm{PO}_{4}{ }^{3--}$ additions. Timecourses plotted in upper panels and uptake rates computed from successive intervals after nutrient additions plotted in lower panels. Kinetic parameters of fitted rectangular hyperbolas listed in Table 3.

cells (9.09 vs. $4.59 \times 10^{5} \mu \mathrm{m}^{3} \cdot \mathrm{ml}^{-1}$ ) and a higher percentage of eucaryotes $(18.7 \%$ of total cell volume) than did the $<5-\mu \mathrm{m}$ fraction.

Bacteria constituted a small fraction of total cell biomass in epilimnetic samples. Samples from $0 \mathrm{~m}$ in Third Sister Lake on 17 August 1981 gave $2.53 \times 10^{6}(\mathrm{SE}=$ $0.78 \times 10^{6}, n=8$ ) cells $\cdot \mathrm{ml}^{-1}$ by direct counts with the acridine orange method (AODC). However, $2.35 \times 10^{6} \quad(\mathrm{SE}=$ $\left.0.45 \times 10^{6}, n=8\right)$ cells $\cdot \mathrm{ml}^{-1}$ fluoresced primarily red or orange without the addition of acridine orange and were pre-

Table 3. Comparison of kinetic parameters (with 95\% C.I.) for $\mathrm{PO}_{4}^{3-}$ uptake by epilimnetic plankton of Third Sister Lake. $V_{\max }$ is expressed both per unit volume and per unit Chl $a$.

\begin{tabular}{|c|c|c|c|c|}
\hline & & \multirow{2}{*}{$\begin{array}{c}K_{\mathrm{s}} \\
(\mathrm{nM})\end{array}$} & \multicolumn{2}{|c|}{$V_{\max }$} \\
\hline & & & $\left(\mathrm{nM} \cdot \mathrm{min}^{-1}\right)$ & $\left(\mathrm{nmol} \cdot \mu \mathrm{g} \mathrm{Chl} a \quad{ }^{1} \cdot \min ^{\prime}{ }^{1}\right)$ \\
\hline 13 Aug & $\begin{array}{r}<55 \mu \mathrm{m} \\
<5 \mu \mathrm{m}\end{array}$ & $\begin{array}{l}338(0-683) \\
278(4-551)\end{array}$ & $\begin{array}{l}64.4(46.5-82.2) \\
53.6(40.2-67.0)\end{array}$ & $\begin{array}{l}11.4(8.2-14.5) \\
10.4(7.8-13.0)\end{array}$ \\
\hline 20 Aug & $\begin{array}{r}>5 \mu \mathrm{m} \\
<55 \mu \mathrm{m}\end{array}$ & $\begin{array}{l}482(266-697) \\
757(340-1,175)\end{array}$ & $\begin{array}{c}1.3(1.2-1.5) \\
108.1(88.0-128.7)\end{array}$ & $\begin{array}{c}2.3(2.0-2.6) \\
23.1(18.8-27.5)\end{array}$ \\
\hline
\end{tabular}




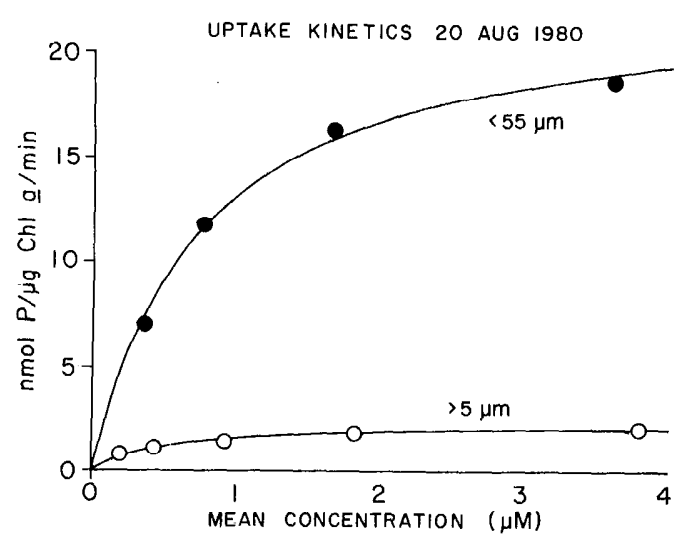

Fig. 4. Uptake kinetics of particles passed through a $55-\mu \mathrm{m}$ sieve ( ) and of those $<55 \mu \mathrm{m}$ but retained on a $5-\mu \mathrm{m}$ sieve $(O)$. Rates represent uptake during first 5 min after nutrient addition. $\mathrm{Pa}$ rameters listed in Table 3.

sumed to contain photosynthetic pigments which autofluoresce (AF). Counts from $3 \mathrm{~m}$, the bottom of the epilimnion, yielded $\mathrm{AODC}=1.74 \times 10^{6}$ cells $\cdot \mathrm{ml}^{-1}$ $\left(\mathrm{SE}=0.33 \times 10^{6}, n=16\right)$ and $\mathrm{AF}=0.64$ $\times 10^{6}$ cells $\cdot \mathrm{ml}^{-1}\left(\mathrm{SE}=0.20 \times 10^{6}, n=\right.$ 12). All eucaryotic cells and obvious bluegreen filaments like Anabaena were omitted from the counts. Most of the cell biomass clearly consisted of autofluorescing cyanobacteria. We conclude that the photosynthetic procaryotes were responsible for the rapid flux of $P$ we measured.

The uptake rates of the small fraction have two major features: they represent very rapid net flux of $P$ into the cells, and they slow quickly when cells are exposed to saturating concentrations of $\mathrm{PO}_{4}{ }^{3-}$. To more clearly illustrate both points, we gave lake water repeated additions of $\mathrm{PO}_{4}{ }^{3-}$ designed to bring concentrations to roughly the same value each time (Figs. $5,6,7)$. In each figure measured concentrations are plotted in the upper panel and percent changes following each addition in the lower panel. It is clear that maximum potential rates of uptake decline markedly with increased duration of exposure to the nutrient, particularly at the higher concentrations (e.g. Figs. 6, 7). When the concentration data are recast as uptake rates over each 5 - or 10 -min in-
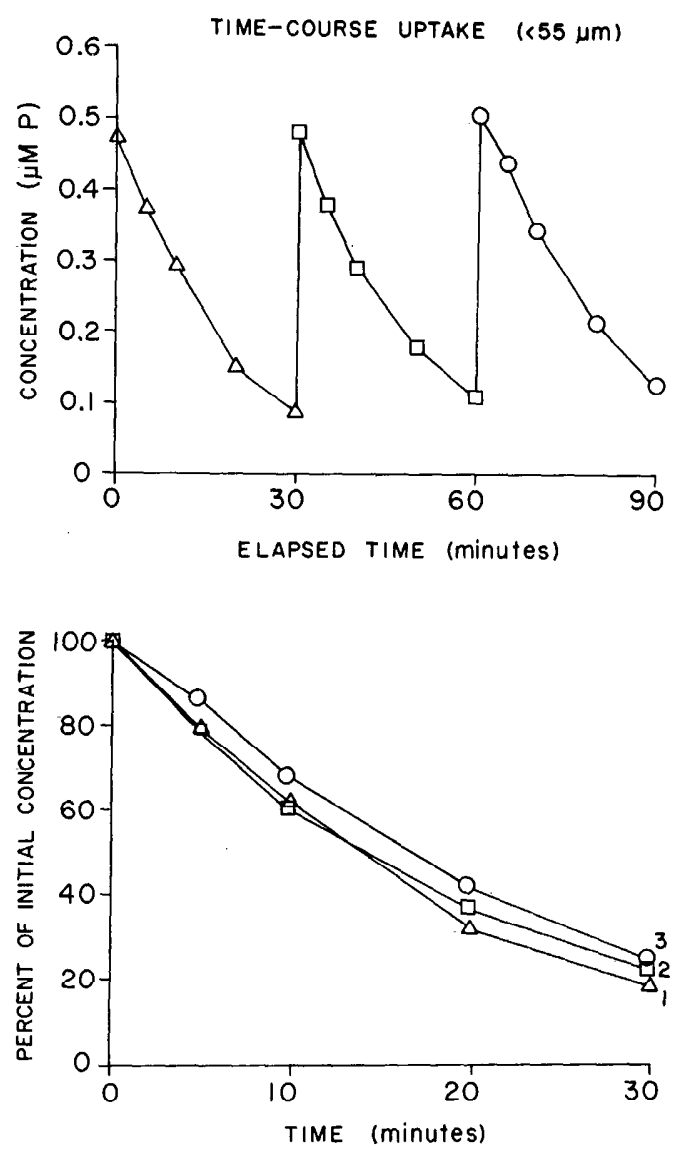

Fig. 5. Measured change in SRP concentration following successive enrichments of lake water to about $0.5 \mu \mathrm{M}$ (upper panel). Percentage decreases in concentration following each addition plotted and coded by number in lower panel. Water was initially sieved through a $55-\mu \mathrm{m}$ mesh.

terval, it becomes clear also that the effect is strongest at saturating concentrations, that is, at those concentrations corresponding to the plateau of the initial uptake curve (Fig. 8). By the second and third $\mathrm{PO}_{4}{ }^{3-}$ addition, uptake rates declincd to a maximum value that is only $28 \%$ of the initial maximum.

To put the fast initial rates in perspective, consider that total particulate $\mathrm{P}$ in the experiment plotted in Fig. 8 was initially $140 \mathrm{nM}$. At the initial $V_{\max }$ of 69.1 $\mathrm{nM} \mathrm{P} \cdot \mathrm{min}^{-1}$, the particulate $\mathrm{P}$ content of the seston could double in $2 \mathrm{~min}$. If some of that measured initial particulate $\mathrm{P}$ were 

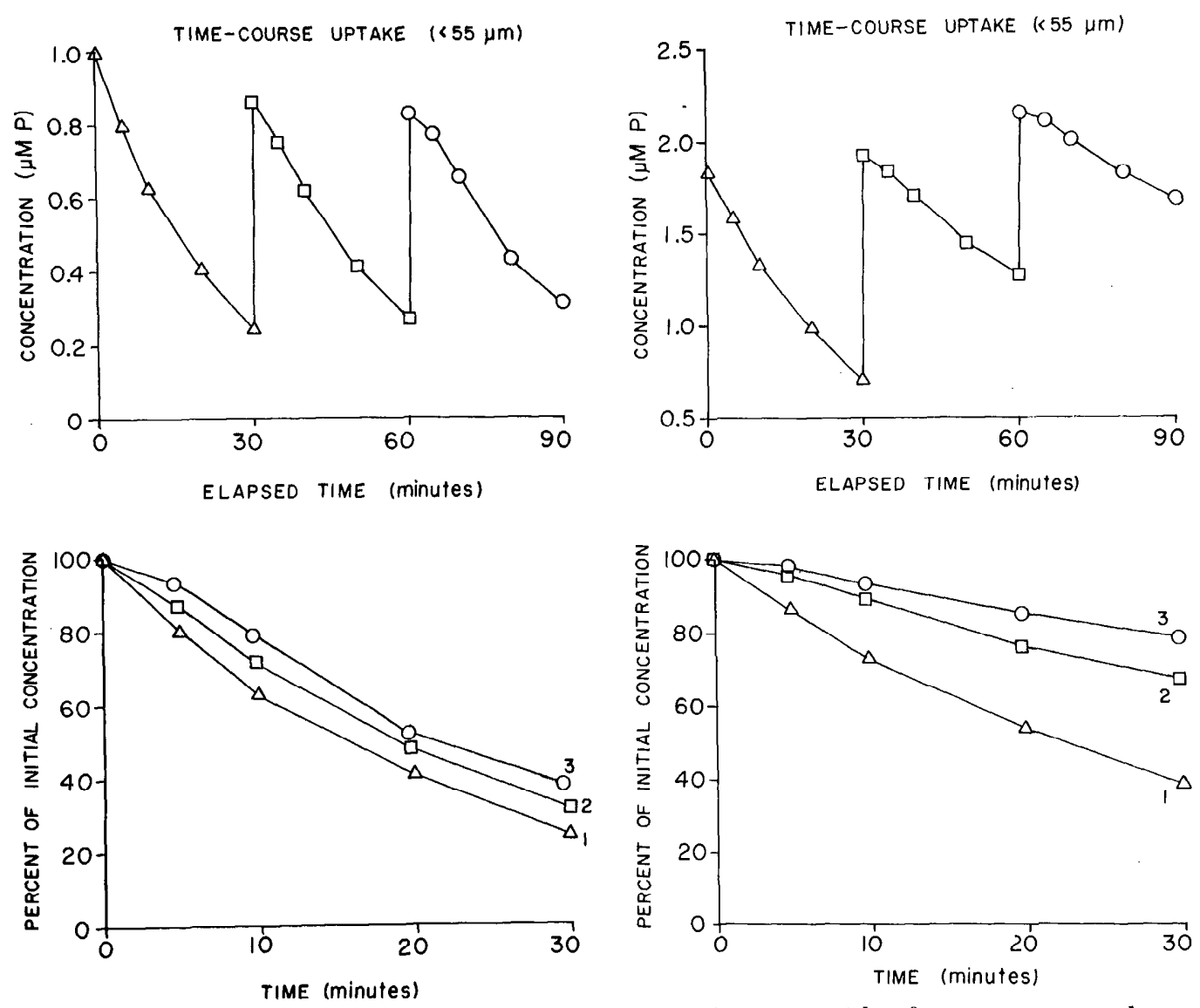

Fig. 6. As Fig. 5, but for successive enrichments to $1.0 \mu \mathrm{MP}$.

abiotic or inactive the doubling time of active biotic $P$ would naturally be even less. The small cells responsible for these rates thus need to be exposed to saturating concentrations for about $1 \mathrm{~min}$ to double their cellular contents of $\mathrm{P}$.

\section{Discussion}

Previous analyses with lake plankton have traditionally focused on kinetics of $\mathrm{PO}_{4}{ }^{3-}$ use at concentrations close to ambient (e.g. Lean and Nalewajko 1979). Perhaps the most important outcome of those studies has been the repeated demonstration that ambient pools of $\mathrm{PO}_{4}{ }^{3-}$ are less than chemical measures of SRP would indicate (Rigler 1966; Levine and Schindler 1980). Although other forms of

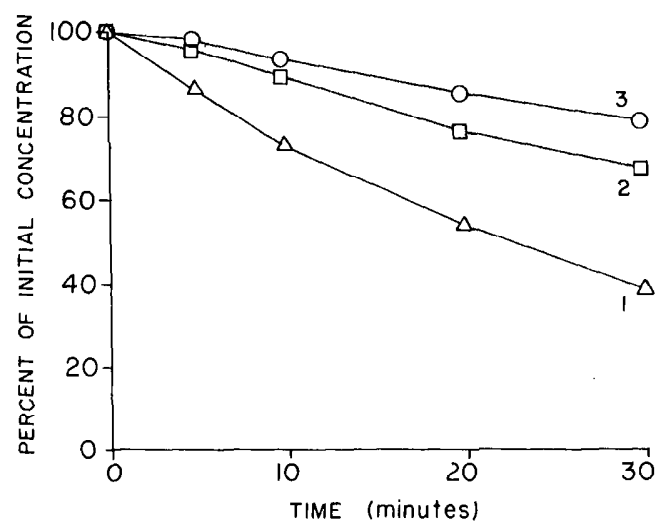

Fig. 7. As Fig. 5, but for successive enrichments to $2.0 \mu \mathrm{M} \mathrm{P}$.

$\mathrm{P}$ are certainly available to the algae (Provasoli 1958$), \mathrm{PO}_{4}{ }^{3-}$ may be the most biologically reactive substrate, judging from the swift turnover times of the pool.

We find an unsettling inconsistency when we try to reconcile these reports with established kinetic data on $\mathrm{PO}_{4}{ }^{3-}$ utilization in algae. The true concentrations of $\mathrm{PO}_{4}{ }^{3-}$ in the epilimnia of many lakes during summer seem insufficient to support measured rates of primary production and cell division. Kilham (1978) for instance, reports half-saturation constants for steady state growth rates of algae limited by $\mathrm{PO}_{4}{ }^{3-}$ ranging from about 0.02 to about $0.3 \mu \mathrm{M} \mathrm{PO}_{4}{ }^{3-}$. Ahlgren (1978) showed that the same parameter varied with temperature for Oscillatoria 


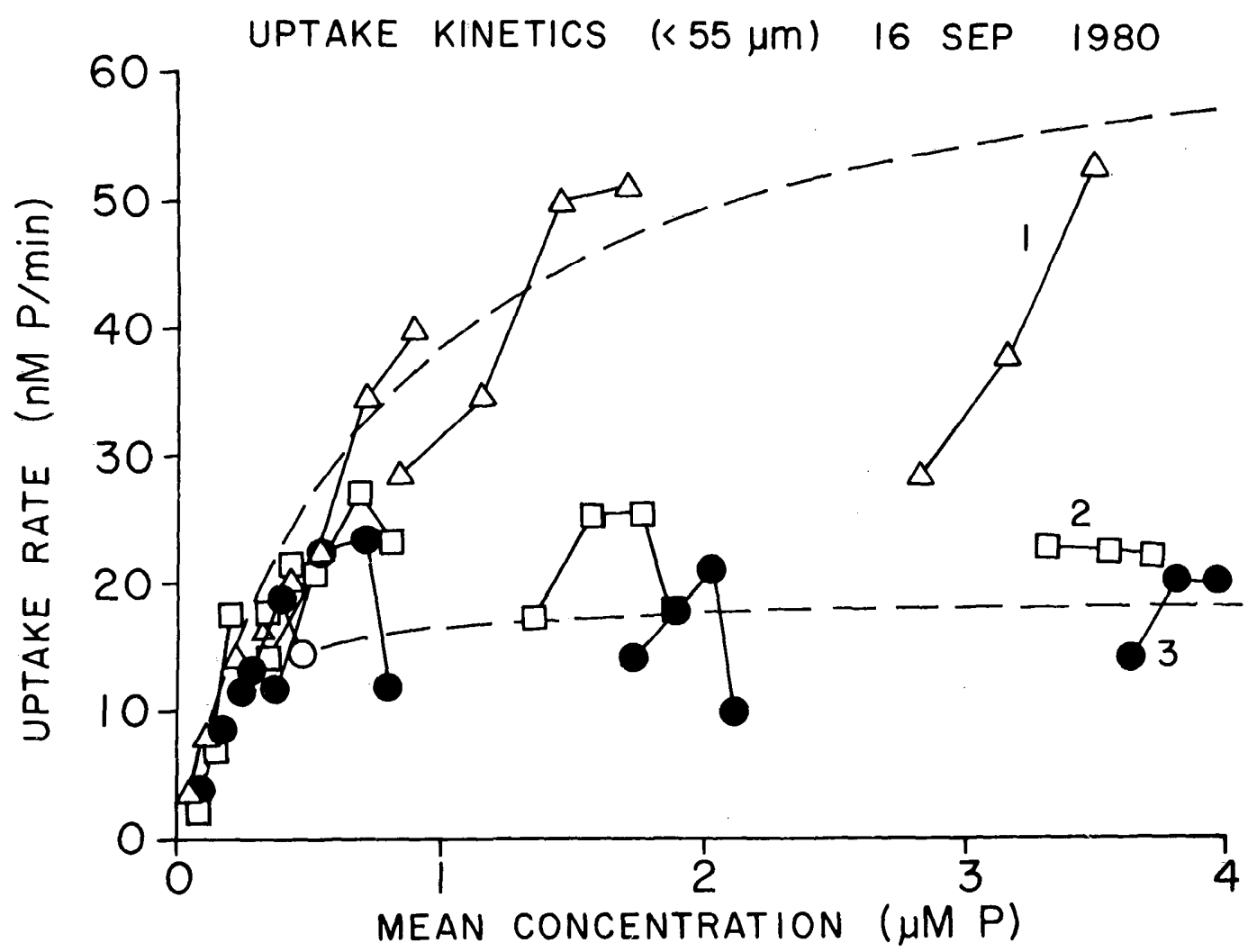

Fig. 8. Uptake rates derived from Figs. 5, 6, 7 plus additional, similar data and plotted as in Fig. 3. Rates measured for successive $\mathrm{PO}_{4}{ }^{3-}$ additions are plotted and coded with different symbols. Two rectangular hyperbolas are plotted. First is fit to first 5 min of uptake data from first $\mathrm{PO}_{4}{ }^{3-}$ addition: $V_{\max }=$ $69.1 \mathrm{nM} \cdot \mathrm{min}^{-1}(95 \%$ C.I. $=44.6-93.6) ; K_{s}=0.79 \mu \mathrm{M}(95 \%$ C.I. $=0.03-1.56)$. Second is fit to rates measured during third $\mathrm{PO}_{4}{ }^{3-}$ addition: $\mathrm{V}_{\max }=19.4 \mathrm{nM} \cdot \min ^{-1}(95 \%$ C.I. $=15.3-23.4) ; K_{s}=0.16 \mu \mathrm{M}(95 \%$ C.I. $=0.01-0.32$ ). Initial measured Chl $a=5.66 \mu \mathrm{g} \cdot \operatorname{liter}^{-1}$, Pheo $a=0.46 \mu \mathrm{g} \cdot \operatorname{liter}^{-1}$, SRP $=1 \mathrm{nM}$, particulate $\mathrm{P}=140 \mathrm{nM}$.

agardhii, ranging from 0.006 to $0.035 \mu \mathrm{M}$ $\mathrm{P}$. Radiochemical analysis of $\mathrm{PO}_{4}{ }^{3-}$ in lake water often suggests about $0.003 \mu \mathrm{M}$ as a maximal concentration in epilimnia during summer (e.g. Levine and Schindler 1980) and true concentrations may often be an order of magnitude or more less than that. Under these conditions, the algae might be expected to be dividing at only a minute fraction of their maximal capacity, certainly at much less than 0.1 divisions $\cdot \mathrm{d}^{-1}$.

Low ambient concentrations of a limiting nutrient take on even greater significance when the possibility of transport-limited rates of uptake is considered (Pasciak and Gavis 1974; Gavis 1976). As external concentrations approach zero, it is progressively more difficult to establish the large concentration gradients near a cell that are needed to sustain high flux rates. The problem is intensified because enzyme-mediated uptake at the cell surface depends on concentrations there, which must be $>0$. Thus when bulk concentrations are excessively low, concentrations at the cell surface are even lower.

Despite these meager prospects, the phytoplankton in Third Sister Lake and elsewhere evidently survive and grow. Algae probably do not always compete in nature, as they do in chemostats, for constant low concentrations of nutrients; the aquatic environment is not homogeneous.

The kinetic properties we measured for 
Table 4. Mean species biomass $\left(10^{6} \mu \mathrm{m}^{3} \cdot \mathrm{ml}^{-1}\right)$ from replicate enclosures enriched with $2 \mu \mathrm{M} \mathrm{PO}_{4}{ }^{3}$ and $30 \mu \mathrm{M} \mathrm{NH}_{4}{ }^{+}$on 24 June.

\begin{tabular}{|c|c|c|c|c|c|c|}
\hline & \multicolumn{3}{|c|}{ Zooplankton present } & \multicolumn{3}{|c|}{ Zooplankton absent } \\
\hline & Initial & Final & $F: I$ & Initial & Final & $F: I$ \\
\hline Unidentified coccoid & 0.24 & 0.19 & 0.77 & 0.16 & 0.88 & 5.50 \\
\hline Microcystis minutissima & 0.30 & 4.31 & 14.46 & 0.24 & 15.96 & 66.50 \\
\hline Lyngbya limnetica & 0.81 & 50.62 & 62.42 & 0.40 & 14.62 & 36.55 \\
\hline
\end{tabular}

the phytoplankton in Third Sister Lake are noteworthy because the rapid maximal uptake rates occur only at concentrations at least 100 times greater than ambient. From an evolutionary perspective we expect to find some adaptive significance associated with those rates. That would be a difficult task if the algae never experienced elevated nutrient levels for brief periods. But clearly they do. Thorpe (1977) has demonstrated subsurface current jets and surges that temporarily produce local instabilities, and Mortimer (1975) has characterized intermittent mixing and events sometimes called temporary "mixing windows" through which nutrient-rich waters from depth are mixed upward into the epilimnion. These are stochastic and short-lived events keyed by physical forces. They occur when local velocities summed from diverse component water movements cause the Richardson's number to fall below its critical value. One biological significance of the phenomenon is that phytoplankton probably experience elevated nutrient levels briefly.

Furthermore, in some lakes, perhaps in most, nutrients are recycled by zooplankton and supplied to the water at rates sufficient to meet algal demands (Lehman 1980). Some workers have already suggested that nonpredatory encounters between algae and zooplankton could yield substantial nutritive benefits to the algae (Goldman et al. 1979), although the notion has been challenged (Jackson 1980). The maximal rates of $\mathrm{PO}_{4}{ }^{3-}$ uptake that we report here are so much greater than the rates considered by these previous workers that the mechanism may be particularly important in lakes, notwithstanding the criticism of oceanic exam- ples. Similar importance can be attached to the high concentrations of nutrients found in the vicinity of organic aggregates (e.g. Shanks and Trent 1979). Evidence that zooplankton create miniature nutrient patches that can be exploited by algae (Lehman and Scavia 1982) makes our claim even more likely.

Since the nannoplankton proved to be so adept at obtaining nutrients in our studies it seems reasonable to ask why they do not dominate the lake more thoroughly and persistently. We believe that the answer lies in the grazing rates of herbivorous zooplankton. In Table 4 we compare the performance of three cyanobacteria from the 24 June experiment in enclosures with ambient lake abundances of zooplankton with those in enclosures from which most animals were removed by sieving the water through a $55-\mu \mathrm{m}$ mesh. The small coccoid cells and Microcystis fared considerably less well in the presence of the animals than in their absence, but the filamentous Lyngbya evidently did just the opposite. Because grazers kept the other cells in check, Lyngbya may have been able to get a larger share of the added $P$, both directly and recycled from the remains of the grazed cells.

\section{References}

AHLGREN, G. 1978. Growth of Oscillatoria agardhii in chemostat culture. 2. Dependence of growth constants on temperature. Mitt. Int. Ver. Theor. Angew. Limnol. 21, p. 88-102.

Berman, T., AND G. W. Skyring. 1979. Phosphorus cycling in aquatic microorganisms studied by phased uptake of ${ }^{33} \mathbf{P}$ and ${ }^{32} \mathbf{P}$. Current Microbiol. 2: 47-49.

Brown, E. J., R. F. Harrus, And J. F. Koonce. 1978. Kinetics of phosphate uptake by aquatic microorganisms: Deviations from a simple Mi- 
chaelis-Menten equation. Limnol. Oceanogr. 23: 26-34.

BurNison, B. K. 1975. Microbial ATP studies. Proc. Int. Assoc. Theor. Appl. Limnol. 19: 286290.

Gavis, J. 1976. Munk and Riley revisited: Nutrient diffusion transport and rates of phytoplankton growth. J. Mar. Res. 34: 161-179.

Goldman, J. C., J. J. MCCarthy, and D. G. PEAVEY. 1979. Growth rate influcnce on the chemical composition of phytoplankton in oceanic waters. Nature 279: 210-215.

Hobbie, J. E., R. J. DALEY, AND S. JASPER. 1977. Use of Nuclepore filters for counting bacteria by fluorescence microscopy. Appl. Environ. Microbiol. 33: 1225-1228.

JACKSON, G. A. 1980. Phytoplankton growth and zooplankton grazing in oligotrophic oceans. Nature 284: 439-441.

KILHAM, S. S. 1978. Nutrient kinetics of freshwater planktonic algae using batch and semicontinuous culture methods. Mitt. Int. Ver. Theor. Angew. Limnol. 21, p. 147-157.

KuENZLER, E. J., AND B. H. KeTCHUM. 1962, Rate of phosphate uptake by Phaeodactylum tricornutum. Biol. Bull. 123: 134-145.

LeAN, D. R. 1973. Phosphorus dynamics in lakewater. Science 179: 678-680.

$\longrightarrow$ AND C. Nalewajko. 1979. Phosphorus turnover time and phosphorus demand in large and small lakes. Arch. Hydrobiol. Beih. Ergeb. Limnol. 13: 120-132.

LEHMAN, J. T. 1980. Release and cycling of nutrients between planktonic algae and herbivores. Limnol. Oceanogr. 25: 620-632.

$\longrightarrow$, AND D. SCAVIA. 1982. Microscale patchiness of nutrients in plankton communities. Science 216: 729-730.

Levine, S. N., AND D. W. SchindLeR. 1980. Radiochemical analysis of orthophosphate concentrations and seasonal changes in the flux of orthophosphate to seston in two Canadian shield lakes. Can. J. Fish. Aquat. Sci. 37: 479-487.
Menzel, D., AND N. CoRwin. 1965. The measurement of total phosphorus in seawater based on the liberation of organically bound fractions by persulfate oxidation. Limnol. Oceanogr. 10: 280-282.

MORTIMER, C. II. 1975. Modelling of lakes as physical-biochemical systems-Present limitations and needs, p. 217-232. In J. C. Nihoul [ed.], Modelling of marine systems. Elsevier Ocean Sci. Ser. V. 10.

PasciaK, W., AND J. Gavis. 1974. Transport limitation of nutrient uptake in phytoplankton. Limnol. Oceanogr. 19: 881-888.

Pearl, H. W., and D. R. Lean. 1976. Visual observations of phosphorus movement between algae, bacteria, and abiotic particles in lake waters. J. Fish. Res. Bd. Can. 33: 2805-2813.

Provasoli, L. 1958. Nutrition and ecology of protozoa and algae. Annu. Rev. Microbiol. 12: 279 308.

RigLeR, F. H. 1966. Radiobiological analysis of inorganic phosphorus in lakewater. Int. Ver. Theor. Angew. Limnol. Verh. 16: 465-470.

1968. Further observations inconsistent with the hypothesis that the molybdenum blue method measures orthophosphate in lake water. I.imnol. Oceanogr. 13: 7-13.

- 1973. A dynamic view of the phosphorus cycle in lakes, p. 539-572. In E. J. Griffith et al. [eds.], Environmental phosphorus handbook. Wiley.

Shanks, A. L., AND J. D. Trent. 1979. Marine snow: Microscale nutrient patches. Limnol. Oceanogr. 24: 850-854.

Strickland, J. D., AND T. R. Pairsons. 1972. A practical handbook of seawater analysis, 2 nd ed. Bull. Fish. Res. Bd. Can. 167.

Thorpe, S. A. 1977. Turbulence and mixing in a Scottish Loch. Phil. Trans. R. Soc. Lond. Ser. A 286: 125-180.

Submitted: 19 October 1981 Accepted: 8 March 1982 